\title{
PRODUKTIVITAS KERJA DOSEN DIPENGARUHI KOMPETENSI, MOTIVASI DAN PENGALAMAN KERJA
}

\author{
Muh. Fahrurrozi ${ }^{1}$, Hary Murcahyanto ${ }^{2}$, Mohzana $^{3}$ \\ Universitas Hamzanwadi ${ }^{1,2,3}$ \\ fahrurrozi@hamzanwadi.ac.id ${ }^{1}$
}

\begin{abstract}
ABSTRAK
Penelitian ini bertujuan untuk mengenali pengaruh kompetensi, motivasi serta pengalaman kerja terhadap produktivitas kerja dosen pada Fakultas Ilmu Sosial serta Ekonomi Universitas Hamzanwadi Lombok Timur baik secara parsial ataupun simultan. Menggunakan pendekatan kuantitatif dengan metode korelasional untuk memastikan apakah terdapat ikatan antara 2 variabel ataupun lebih. Populasi, semua dosen Fakultas Ilmu Sosial serta Ekonomi yang berjumlah 32 orang dosen. Metode pengambilan sampel memanfaatkan cara sampling jenuh. Tata cara analisis informasi memakai deskriptif informasi, uji prasyarat analisis informasi, pengujian hipotesis. Analisis informasi pengaruh kompetensi, motivasi serta pengalaman kerja terhadap produktivitas kerja dosen diolah memakai SPSS16. 0 for windows. Hasil riset uji t menampilkan kalau tiap-tiap variabel independen ialah kompetensi serta motivasi kerja secara parsial mempengaruhi positif serta signifikan, sebaliknya pengalaman kerja secara parsial tidak mempengaruhi produktivitas kerja. Hasil riset uji $\mathrm{F} 70 \%$ produktivitas kerja dipengaruhi oleh aspek kompetensi, motivasi serta pengalaman kerja sebaliknya sisanya sebesar 30\% diuraikan ataupun diprediksikan oleh aspek lain di luar ketiga aspek serta model lain di luar model tersebut. Simpulan, secara parsial bahwa variabel kompetensi lebih berpengaruh dibandingkan variabel motivasi dan pengalaman kerja terhadap produktifitas kerja, namun secara simultan variable kompetensi, motivasi dan pengalaman kerja perpengaruh terhadap produktivitas kerja dosen.
\end{abstract}

Kata Kunci: Produktivitas Kerja, Motivasi Kerja, Pengalaman Kerja

\section{ABSTRACT}

This study aims to identify the effect of competence, motivation and work experience on the work productivity of lecturers at the Faculty of Social Sciences and Economics, Hamzanwadi University, East Lombok, either partially or simultaneously. Using a quantitative approach with a correlational method to ascertain whether there is a bond between 2 or more variables. The population, all lecturers of the Faculty of Social Sciences and Economics, totaling 32 lecturers. The sampling method utilizes saturated sampling method. Information analysis procedures use descriptive information, information analysis prerequisite test, hypothesis testing. Information analysis of the influence of competence, motivation and work experience on lecturers' work productivity is processed using SPSS16. O for windows. The results of the t-test research show that each independent variable, namely competence and work motivation, partially affects positively and significantly, whereas work experience partially does not affect work productivity. The results of the F test research $70 \%$ of work productivity is 
influenced by aspects of competence, motivation and work experience, on the other hand the remaining $30 \%$ is described or predicted by other aspects outside the three aspects and other models outside the model. The conclusion is partially that the competence variable is more influential than the motivation and work experience variables on work productivity, but simultaneously the competence, motivation and work experience variables affect the lecturer's work productivity.

Keywords: Work Productivity, Work Motivation, Work Experience

\section{PENDAHULUAN}

Sumber daya manusia dalam sesuatu sistem operasional perguruan tinggi ialah salah satu modal dasar, memegang sesuatu kedudukan yang berarti dalam mencapai tujuan perguruan inggi. Oleh sebab itu perguruan tinggi perlu mengelola serta meningkatkan sumber daya manusia dengan baik. Karena kunci sukses sesuatu perguruan tinggi bukan hanya pada keunggulan teknologi serta tersedianya dana saja. Namun aspek manusia merupakan aspek yangpaling penting. Sumber daya manusia memegang peran penting dalam tiap penyelenggaraan aktivitas perguruan tinggi walaupun peran serta guna dari tenaga kerja sudah banyak digantikan dengan teknologi yang semakin canggih. Namun pada realitasnya hingga dikala ini tenaga kerja masih jadi aspek yang berarti dalam memastikan jalannya proses penciptaan. Hingga dari itu tiap perguruan tinggi menghendaki supaya setiap tenaga kerja bisa bekerja secara efisien serta efektif.(Al Shobaki, Naser, Amuna, \& El Talla, 2017; Hanggraeni, 2012; Langford, et.al, 2014; Masri \& Jaaron, 2017; Samsuni, 2017; Sutrisno, 2019).

Pengembangan sumber daya manusia, baik pada sektor publik maupun swasta, perlu dilakukan secara terencana dan berkesinambungan. Strategi untuk mengembangkan sumber daya manusia, yang dikenal sebagai manajemen organisasi, harus fleksibel dalam menerima gagasan-gagasan baru bahkan apabila pada saat ini kurang tepat dan dapat melakukan beberapa perubahan mendasar terhadap kebijakan konvensional. (Al Shobaki et al., 2017; Masri \& Jaaron, 2017; Sutrisno, 2019). Kemampuan dosen baru yang telah mengikuti program pengenalan dan pelatihan dosen tertentu, belum seutuhnya menjadikan keberhasilan dalam kemampuan kerja maupun tuntutan tugas yang akan bermuara pada peningkatan produktivitas kerja dosen secara keseluruhan (Aristarini, et.al, 2014; Fahlefi, 2016; Kinanti \& Zuraida, 2018; Hambali, 2021).

Produktivitas kerja dosen adalah suatu akibat dari salah satu persyaratan kerja yang wajib dipenuhi oleh setiap dosen yakni keseimbangan antara pendidikan, pengajaran, penelitian, dan pengabdian masyarakat meskipun ada unsur penunjang yang bisa dimanfaatkan. (Sari, 2015; Hayati \& Lolytasari, 2017; Heri, 2019; Dewi, 2019). Syarat tersebut merupakan syarat kesediaan dosen pada saat awal diterima untuk bekerja dengan penuh semangat dan tanggung jawab. Seorang dosen yang memenuhi prasyarat kerja adalah dosen yang dianggap mempunyai kemampuan, jasmani yang sehat, kecerdasan, dan pendidikan minimal 
S2 dan telah memperoleh pendidikan keterampilan khusus sebagai dosen untuk melaksanakan tugas dan memenuhi syarat yang memuaskan dari segi kualitas maupun kuantitas. (Dewi, 2019; Hayati \& Lolytasari, 2017; Heri, 2019).

Kompetensi dosen, motivasi dan pengalaman kerja dosen maupun karyawan yang baik dapat menunjang keberhasilan suatu institusi atau perguruan tinggi dalam mencapai tujuannya. (Ratulangi \& Soegoto, 2016;Murcahyanto \& Asmawi, 2019;Rosmaini \& Tanjung, 2019). Adanya faktor tersebut akan meningkatkan produktivitas kerja dosen sehingga akan menunjang keberhasilan pada perguruan tinggi atau institusi. Bagitu pula sebaliknya apabila produktivitas kerja menurun maka capaian pada perguruan tinggi akan terhambat. (Hambali, 2021; Kinanti \& Zuraida, 2018).

Kompetensi dosen, motivasi dan pengalaman kerja dosen adalah suatu hal yang berperan penting dalam meningkatkan efektivitas kerja dosen pada perguruan tinggi. (Fahrurrozi, et.al, 2020). Sebab seorang dosen yang memiliki kompetensi, motivasi dan pengalaman kerja yang tinggi pasti akan berusaha semaksimal mungkin agar capaian dalam pekerjaannya dapat berhasil dengan baik,dan akan meningkatkan produktivitas kerja. (Hambali, 2021; Heri, 2019).

Pada setiap institusi atau perguruan tinggi selalu menginginkan agar setiap dosennya memiliki produktivitas yang tinggi dan selalu meningkat. Maka motivasi sangat diperlukan dalam mencapai hal tersebut. (Dewi, 2019; Fahlefi, 2016; Hambali, 2021; Hayati \& Lolytasari, 2017; Heri, 2019; Sari, 2015). Pengalaman kerja dan kompetensi yang dimiliki oleh para dosen, akan memberikan suatu hubungan dan pengaruh yang kuat dalam upaya mencapai tingkat produktivitas yang tinggi. (Hamzah, 2008; Hasibuan, 2005). Hasil temuan yang dilakukan oleh Asih, (2020) kompetensi tidak berpengaruh terhadap kinerja dosen akan tetapi motivasi sangat berpengaruh terhadap kinerja dosen. (Rozada, 2020) menemukan bahwa variabel Kompetensi berpengaruh terhadap kinerja dosen, variabel motivasi kerja tidak berpengaruh terhadap kinerja dosen. Disiplin kerja berpengaruh terhadap kinerja dosen. Beberapa penelitian juga menunjukkan bahwa motivasi berpengaruh terhadap kinerja (Hidayanto, 2016; Hidayati, 2015; I'tidal \& Jam'an, 2016; Rohmat, 2020; Sa'adah, 2015; Utama, 2018).

Berdasarkan penelitian terdahulu telah banyak membahas tentang produktifitas kerja dipengaruhi oleh variable kompetensi, motivasi dan pengalaman kerja, namun dalam penelitian ini akan mengkaji lebih mendalam tentang produktifitas kerja dosen dalam hal ketaatan terhadap jam kerja yang masih belum maksimal, hal ini dapat dilihat dari masih adanya beberapa dosen yang hadir tidak tepat waktu tanpa alasan yang jelas, kurangnya upah dosen, penggunaan alat-alat yang masih belum efisien, sehingga hal ini dapat berdampak pada produktifitas kerja. 


\section{METODE PENELITIAN}

Menggunakan pendekatan kuantitatif dengan metode korelasional, guna memastikan apakah terdapat ikatan antara 2 variabel ataupun lebih. Penelitian ini dilakukan di Fakultas Ilmu Sosial dan Ekonomi Universitas Hamzanwa ditahun 2019. Populasi dalam penelitian ini adalah seluruh dosen pada Fakultas Ilmu Sosial dan Ekonomi Universitas Hamzanwadi berjumlah 32 orang dosen. Populasi yang merupakan wilayah generalisasi terdiri atas: objek/subjek yang mempunyai kualitas dan karakteristik tertentu yang ditetapkan oleh peneliti untuk dipelajari dan kemudian ditarik simpulannya. Sedangkan menurut (Suharsimi, 2006) populasi merupakan keseluruhandari semua subjek penelitian. Sampel dalam penelitian ini adalah semua dosen yang ada pada Fakultas IlmuSosial dan Ekonomi Universitas Hamzanwadi yang berjumlah 32 orang dosen.

Variabel yang digunakan dalam penelitian ini sebanyak 4 variabel yaitu: variabel bebas pada kompetensi kerja(X1), motivasi kerja (X2), pengalaman kerja(X3). Sedangkan variabel terikat yakni pada Produktivitas kerja(Y).

Pengumpulan data dilakukan dengan cara observasi langsung yaitu dengan pengamatan langsung pada objek penelitian dengan tujuan untuk mengetahui secara jelas proses pelayanan yang dilakukan. Selain itu juga menggunakan kuesioner dengan cara memberikan seperangkat pertanyaan atau pernyataan tertulis kepada responden untuk dijawab. Dokumentasi digunakan sebagai data sekunder dalam mencari data pelengkap berupa catatan, buku, notulen rapat dan sebagainya.

Pada penelitian ini menggunakan instrument berupa alat dan diuji menggunakan uji validitas data dan uji reabilitas. Teknik yang digunakan untuk uji validitas adalah teknik korelasi Pearson Product Moment. Pengujian validitas dibantu menggunakan program SPSS23 for windows dilakukan dengan cara mengkorelasikan masing-masing pertanyaan dengan skor total. Pengujian validitas dibantu menggunakan program. Nilai korelasi(r) dibandingkan dengan angka kritis dalam tabel korelasi, untuk menguji koefisien korelasi digunakan taraf sifnifikansi $5 \%$ dan jika r-hitung>r-tabel maka pertanyaan tersebut dinyatakan valid.

Pada teknik analisis data menggunakan uji Normalitas, uji Multikolinearitas, dan uji Heteroskedatisitas. Pada uji normalitas bertujuan untuk menguji apakah dalam model regresi, variabel pengganggu atau residual memiliki distribusi normal. Dalam penelitian ini statistik non-parametrik Kolmogrov- Smirnov (K-S). Uji (K-S) dilakukan dengan membuat hipotesis. Pada uji multikolinieritas pada suatu model dapat dilihat dari beberapa hal antara lain. Jika nilai Variance Inflantion Factor (VIF) tidak lebih dari 10 dan nilai tolerance tidak kurang dari 0,1 , maka model tersebut dapat dikatakan terbebas dari multikolinieritas. Sedangkan pada uji Heteroskedastisitas, dengan cara memprediksi ada tidaknya heterokedastisitas pada suatu model gambar Scatterplot model tersebut. Analisis pada 
gambar Scatterplot yang menyatakan model regresi linier sederhana tidak terdapat heteroskedatisitas jika: a) Titik titik data menyebar diatas dan dibawah atau disekitar angka 0 . b) Titik titik data tidak mengumpul hanya diatas atau dibawah saja. c) Penyebaran titik titik data tidak boleh membentuk pola bergelombang, melebar kemudian menyempit. dan d) Penyebaran titik titik data sebaiknya tidak berpola.

Pengujian Hipotesis menggunakan Uji t (Uji Parsial) dan uji F (Uji Simultan). Pada uji t atau uji koefisien regresi secara persial digunakan untuk mengetahui apakah secara persial variabel independen berpengaruh secara signifikan atau tidak terhadap variabel dependen. Dalam hal ini untuk mengetahui apakah motivasi dan pengalaman kerja berpengaruh terhadap produktivitas kerja dosen. Langkah selanjutnya yaitu Thitung dibandingkan dengan Ttabel dengan ketentuan taraf signifikasi $5 \%$ dan $\mathrm{dk}=(\mathrm{n}-2)$. Sedangkan pada Uji F atau uji koefisien regresi secara bersama-sama digunakan untuk mengetahui apakah secara bersama-sama variabel independen berpengaruh terhadap variabel dependen. Nilai Koefisien Determinasi menunjukkan seberapa besar variasi varibel dependen dijelaskan oleh variasi dari variabel independen. Semakin besar nilai $R^{2}$ menunjukkan bahwa semua variabel independen dapat menjelaskan variabel dependen.

\section{HASIL PENELITIAN}

Uji normalitas dimaksudkan untuk mengetahui apakah residual terstandarisasi yang diteliti berdistribusi normal atau tidak. Penyebab tidak normal disebabkan karena terdapat nilai ekstrim dalam data yang kita ambil. Normalitas atau variable umumnya dideteksi dengan uji statistik Kolmogorof-Smirnov (K-S). Suatu variabel dikatakan terdistribusi normal jika nilai signifikannya $>0,05$. Berikut hasil perhitungan uji normalitas menggunakan Kolmogorov-Smirnov:

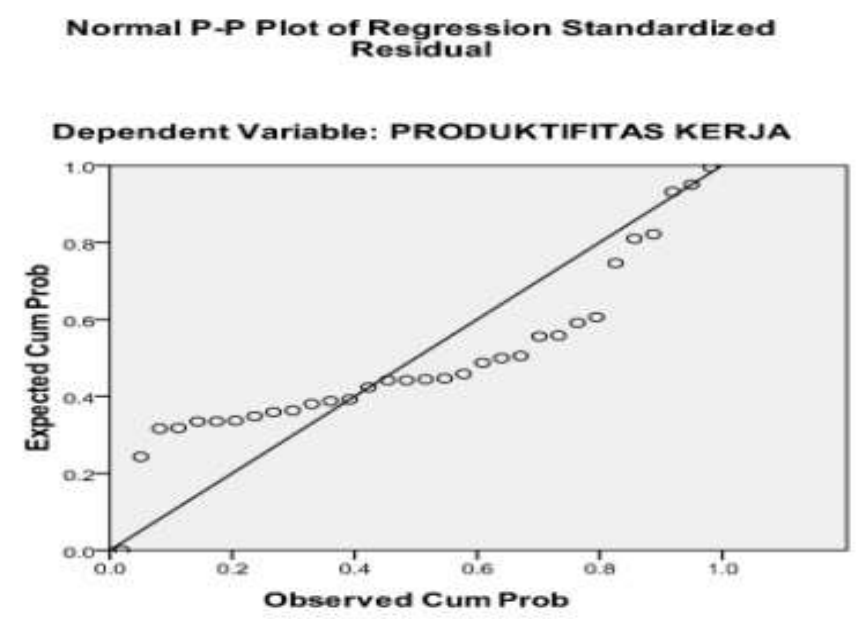

Gambar 1: Hasil Uji Normalitas 
Berdasarkan gambar di atas dapat dilihat bahwa hubungan antara variabel kompetensi, motivasi dan pengalaman kerja terhadap produktivitas kerja menunjukkan pola terdistribusi normal dimana data menyebar disekitar garis diagonal, maka model regresi memenuhi asumsi normalitas.

Uji multikolineritas ini bertujuan untuk menguji apakah model regresi ditemukan adanya korelasi antar variabel bebas. Model regresi yang baik seharusnya tidak terjadi korelasi diantara variabel bebas. Untuk menguji ada tidaknya korelasi antara variabel bebas digunakan metode Tolerance dan Variance Inflation Factor (VIF).

Tabel 1: Hasil Uji Multikolineritas

Coefficients $^{\mathrm{a}}$

\begin{tabular}{|l|l|}
\hline \multicolumn{2}{|l|}{ Collinearity Statistics } \\
\hline Tolerance & VIF \\
\hline & \\
.436 & 2.293 \\
.420 & 2.380 \\
.941 & 1.063 \\
\hline
\end{tabular}

Berdasarkan tabel di atas menjelaskan bahwa nilai Tolerance variabel Kompetensi Kerja $\left(\mathrm{X}_{1}\right)$ 0,436, Motivasi Kerja $\left(\mathrm{X}_{2}\right)$ 0,420, dan Pengalaman Kerja $\left(\mathrm{X}_{3}\right)$ 0,941 yakni lebih besar dari 0,10. Sementara itu, nilai VIF variabel Kompetensi Kerja $\left(X_{1}\right)$ 2,293, Motivasi Kerja $\left(X_{3}\right)$ 2,380 dan Pengalaman Kerja $\left(\mathrm{X}_{3}\right)$ yaitu 1,063 lebih kecil dari 10,00. Sehingga dapat disimpulkan tidak terjadi multikolineritas.

Uji heteroskedastisitas digunakan untuk menguji apakah dalam suatu model regresi terdapat kesamaan atau ketidaksamaan varians antara pengamatan yang satu dengan pengamata yang lainnya. Pengujian heteroskedastisitas dengan menggunakan grafik scatterplot. tidaknya heteroskedastisitas pada suatu model dapat dilihat dengan pola gambar Scatterplot.

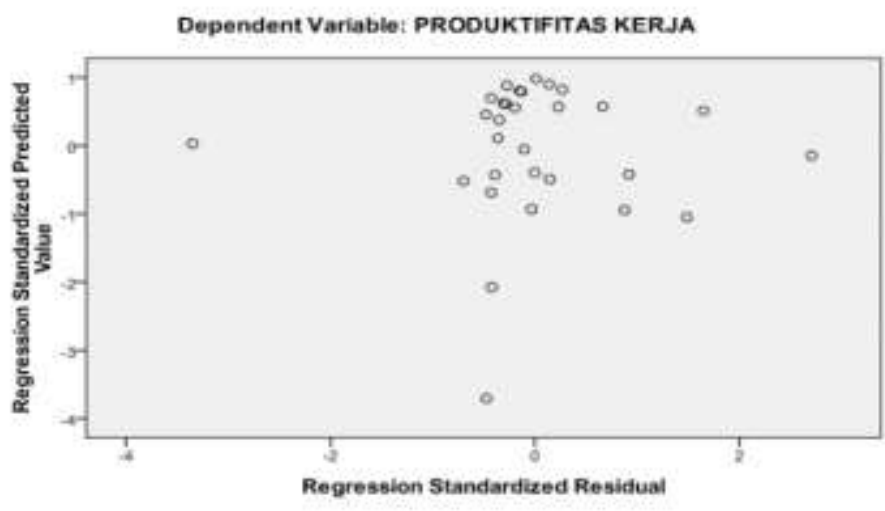

Gambar 2: Hasil Uji Heteroskedastisitas 
Melalui grafik scatterplot dapat dilihat suatu model regresi mengalami heteroskedastisitas atau tidak. Jika terdapat pola tertentu dalam grafik maka mengindikasikan telah terjadi heteroskedastisitas. Dari Gambar terlihat bahwa titik-titik menyebar secara acak serta tersebar baik di atas maupun di bawah angka 0 pada sumbu $Y$. maka dapat disimpulkan bahwa tidak terjadi heteroskedastisitas pada model regresi dalam penelitian ini.

\section{Deskriptif Data}

Data Kompetensi kerja diperoleh melalui angket yang terdiri dari 10 item pertanyaan dengan 10 alternatif jawaban. Dari hasil skoring angket motivasi kerja diperoleh skor tertinggi 48 dan skor terendah adalah 28 dengan rata -rata skor sebesar 42,29, median sebesar 43, modus sebesar 45, standar deviasi (simpangan baku) sebesar 2,26.

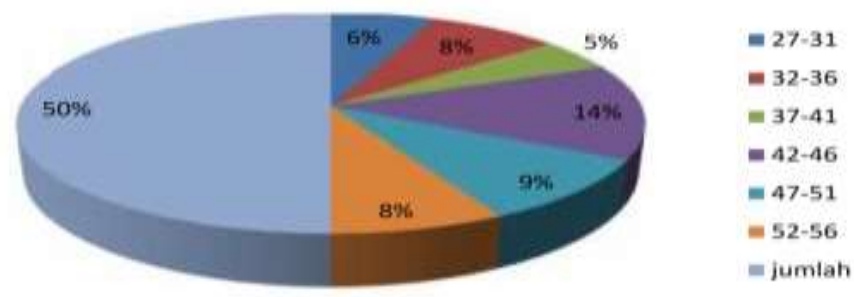

Gambar 3: Diagram Kompetensi Kerja

Berdasarkan diagram di atas menunjukkan bahwa frekuensi terbanyak adalah skor kompetensi kerja antara 42 - 46 yaitu sebanyak 14\%. Sedangkan frekuensi terendah adalah kompetensi kerja antara 37 - 41 yaitu sebanyak 5\%. Data Motivasi kerja diperoleh melalui angket yang terdiri dari 10 item pertanyaan dengan 10 alternatif jawaban. Dari hasil skoring angket motivasi kerja diperoleh skor tertinggi 46 dan skor terendah adalah 27 dengan rata -rata skor sebesar 41,75, median sebesar 43,5, modus sebesar 45, standar deviasi (simpangan baku) sebesar 2,27.

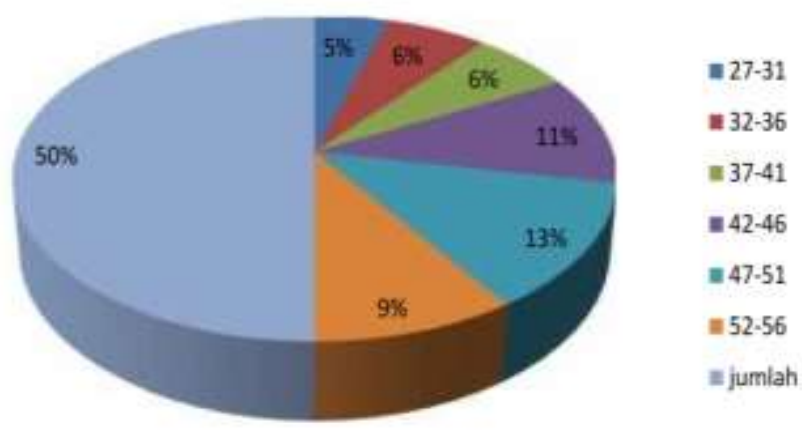

Gambar 4: Diagram Motivasi Kerja 
Berdasarkan diagram di atas menunjukkan bahwa frekuensi terbanyak adalah skor motivasi kerja antara $47-51$ yaitu sebanyak 13\%. Sedangkan frekuensi terendah adalah motivasi kerja antara 27 - 31 yaitu sebanyak 5\%. Data pengalaman kerja diperoleh melalui angket yang terdiri dari 10 item pertanyaan dengan 10 alternatif jawaban. Dari hasil skoring angket pengalaman kerja diperoleh skor tertinggi 49 dan skor terendah adalah 28 dengan rata-rata skor sebesar 41,31, median sebesar 43, modus sebesar 44, standar deviasi (simpangan baku) sebesar 2,31.

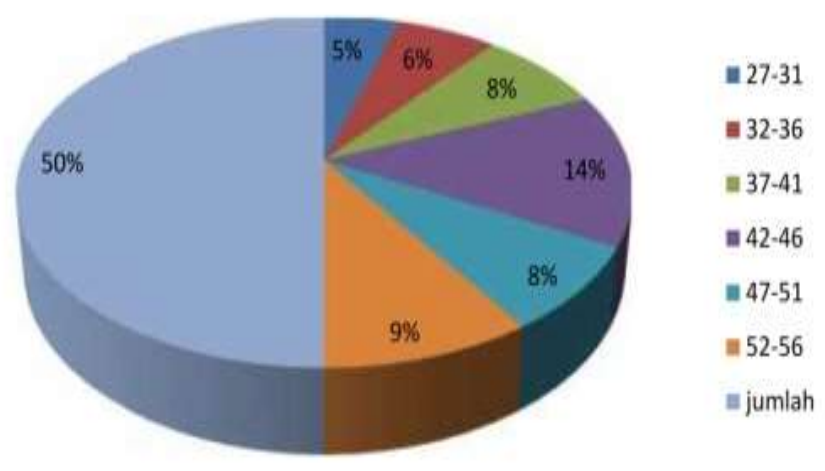

Gambar 5: Diagram Pengalaman Kerja

Berdasarkan diagram di atas menunjukkan bahwa frekuensi terbanyak adalah skor pengalaman kerja antara 42-46 yaitu sebanyak 14\%. Sedangkan frekuensi terendah adalah motivasi kerja antara 27 - 31 yaitu sebanyak 5\%. Data tentang produktivitas kerja diperoleh melalui angket yang terdiri dari 10 item pertanyaan dengan 10 alternatif jawaban. Dari hasil skoring angket produktivitas kerja diperoleh skor tertinggi 48 dan skor ter endah adalah 28 dengan rata- rata skor sebesar 42,43, median sebesar 43,5, modus sebesar 45, standar deviasi (simpangan baku) sebesar 2,29.

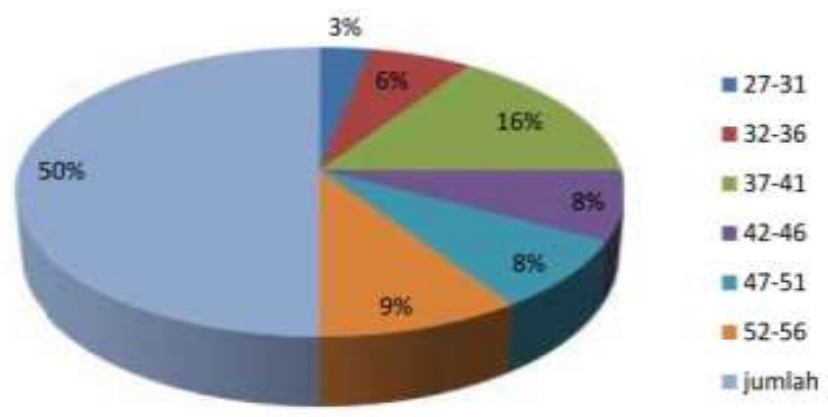

Gambar 6: Diagram Produktivitas Kerja

Berdasarkan diagram di atas menunjukkan bahwa frekuensi terbanyak adalah skor produktivitas kerja antara 37 - 41 yaitu 16\%. Sedangkan frekuensi terendah adalah motivasi kerja antara $27-31$ yaitu $3 \%$. 


\section{PEMBAHASAN}

Pada Uji t merupakan pengujian secara individu dari Koefisien Regresi Parsial variabel independen, digunakan untuk menguji signifikansi pengaruh masing- masing variabel independen dan variabel dependen. (Anshori \& Iswati, 2019; Suliyanto \& MM, 2017; Unaradjan, 2019; Yusuf, 2016). Uji statistiknya adalah uji statistik t dan hipotesis yang diajukan yaitu: Variabel kompetensi kerja, variabel motivasi kerja, dan variabel pengalaman kerja dosen. Pada variabel kompetensi kerja, berdasarkan hasil perhitungan didapatkan nilai $\mathrm{T}_{\text {hitung }}$ sebesar 4,059 dengan nilai signifikansi 0,000 lebih kecil dari 0,05 sedangkan nilai $\mathrm{T}_{\text {tabel }}$ sebesar 2,05, hal ini berarti Ha diterima dan Ho di tolak artinya secara parsial variabel kompetensi kerja berpengaruh signifikan terhadap produktivitas kerja.

Pada variabel motivasi kerja, berdasarkan hasil perhitungan didapatkan nilai $\mathrm{T}_{\text {hitung }}$ sebesar 2,142 lebih besar dari $\mathrm{T}_{\text {tabel }}$ sebesar 2,05 dan memiliki nilai signifikansi 0,041 lebih kecil dari 0,05. Artinya variabel motivasi kerja memiliki pengaruh yang positif dan sifnifikan terhadap produktivitas kerja dapat disimpulkan Ha di terima dan Ho ditolak. Pada variabel pengalaman kerja, berdasarkan hasil perhitungan didapatkan nilai $\mathrm{T}_{\text {hitung }}$ sebesar 0,341 lebih kecil dari $\mathrm{T}_{\text {tabel }}$ sebesar 2,05 dan memiliki nilai signifikansi 0,735 lebih besar dari 0,05 . Artinya variabel pengalaman kerja tidak berpengaruh terhadap produktivitas kerja, dengan demikian Ho diterima dan Ha ditolak. Pada Uji F merupakan pengujian secara bersama-sama Koefisien Regresi Parsial dari variabel independen untuk mengetahui apakah seluruh variabel independen secara bersama-sama memepengaruhi variabel dependen (Anshori \& Iswati, 2019; Suliyanto \& MM, 2017; Unaradjan, 2019; Yusuf, 2016). Uji statistiknya adalah uji statistik $\mathrm{F}$ dan hipotesis yang diajukan yaitu: Berdasarkan hasil perhitungan Uji $F$ diproleh nilai $F_{\text {hitung }}$ sebesar 26,583 dengan nilai signifikansi 0,000. Karena nilai $F_{\text {hitung }}>F_{\text {tabel }}(26,583>2,95)$ dan nilai signifikansinya jauh lebih kecil dari 0,05 , maka model regresi dapat digunakan untuk memprediksi produktivitas kerja atau dapat dikatakan bahwa kompetensi kerja, motivasi kerja dan pengalaman kerja secara bersama-sama berpengaruh terhadap produktivitas kerja dosen.

Pada nilai Koefisien Determinasi $\left(\mathrm{R}^{2}\right)$ menunjukkan seberapa besar variasi varibel dependen dijelaskan oleh variasi dari variabel independen. Semakin besar nilai $R^{2}$ menunjukkan bahwa semua Variabel Independen dapat menjelaskan Variabel Dependen. Berdasarkan hasil perhitungan koefisien determinasi didapat nilai Adjusted $R$ Square atau kemampuan kompetensi kerja (X1), motivasi kerja(X2), pengalaman kerja (X3), dan produktivitas kerja (Y) sebesar 70\%. Hal ini berarti variabel-variabel independent sudah cukup memberikan informasi yang dibutuhkan untuk memprediksi variasi variabel dependennya. Dan sisanya sebesar $30 \%$ dijelaskan atau diprediksikan oleh faktor lain di luar 
ketiga faktor dan model lain di luar model tersebut.

Dari hasil analisa data menunjukkan bahwa untuk variabel Kompetensi kerja (X1) diperoleh nilai $t_{\text {hitung }}$ sebesar 4,059 lebih besar dari $t_{\text {tabel }}$ sebesar 2,05 dan memiliki nilai signifikansi 0,000 lebih kecil dari 0,05. Artinya variabel kompetensi kerja memiliki pengaruh yang positif dan signifikan terhadap produktivitas kerja dapat disimpulkan $\mathrm{Ha}_{1}$ di terima dan $\mathrm{H}_{1}$ ditolak. Hasil analisa data juga menunjukkan bahwa untuk variabel Motivasi kerja (X2) diperoleh nilai $\mathrm{t}$ hitung 0,647 dan $\mathrm{t}$ tabel 2,059, artinya variabel pelayanan tidak signifikan thitung sebesar 2,142 lebih besar dari tabel sebesar 2,05 $(2,142>2,05)$ dan nilai signifikansi 0,000 lebih kecil dari 0,05, sehingga $\mathrm{Ha}_{2}$ diterima dan $\mathrm{HO}_{2}$ ditolak. Motivasi sebagai suatu penentu tercapainya suatu tujuan dengan kata lain motivasi menjadi salah satu pendorong yang kuat untuk bekerja lebih baik dan dapat melahirkan prestasi kerja dosen. Sejalan juga seperti temuan yang dilakukan (Hetharia, et.al, 2019).

Berdasarkan hasil analisa data menunjukkan bahwa untuk variabel Pengalaman kerja (X3) yang dilakukan diperoleh nilai $\mathrm{T}$ hitung sebesar 0,341 lebih besar dari Ttabel sebesar 2,05 $(0,341<2,05)$ dan nilai signifikansi 0,735 lebih besar dari 0,05 , sehingga $\mathrm{HO}_{3}$ diterima dan $\mathrm{Ha}_{3}$ ditolak. Dengan pengalaman yang didapat, dosen akan lebih cakap dan terampil serta mampu melaksanakan tugas pekerjaannya, sehingga mampu meningkatkan produktivitas kerja. Pengalaman kerja tidak hanya menyangkut jumlah masa kerja, tetapi lebih dari juga memperhitungkan jenis pekerjaan yang pernah atau sering dihadapi. Sejalan dengan bertambahnya pekerjaan, maka akan semakin bertambah pula pengetahuan dan keterampilan dosen. Pada hasil uji hipotesis yang ketiga yaitu membandingkan nilai $F_{\text {hitung }}$ sebesar 26,583 dengan nilai signifikansi 0,000. Karena nilai $F_{\text {hitung }}>F_{\text {tabel }}(26,583>2,95)$ dan nilai signifikansinya jauh lebih kecil dari 0,05, maka model regresi dapat digunakan untuk memprediksi produktivitas kerja atau dapat dikatakan bahwa kompetensi kerja, motivasi kerja dan pengalaman kerja secara bersama-sama berpengaruh terhadap produktivitas kerja dosen. Sejalan seperti temuan Hidayanto, (2016) pertama terdapat hubungan kompensasi dengan kinerja dosen kedua Terdapat hubungan yang signifikan antara kompetensi dengan kinerja dosen ketiga Terdapat hubungan motivasi dengan kinerja dosen keempat Motivasi secara simultan memiliki pengaruh terhadap kinerja dosen dibandingkan factor Kompensasi dan kompetensi.

\section{SIMPULAN}

Secara parsial bahwa variable kompetensi lebih berpengaruh dibandingana variabel motivasi dan pengalaman kerja terhadap produktifitas kerja, namun secara simultan variable kompetensi, motivasi dan pengalaman kerja perpengaruh terhadap produktivitas kerja dosen. 


\section{DAFTAR PUSTAKA}

Al Shobaki, M. J., Naser, S. S. A., Amuna, Y. M. A., \& El Talla, S. A. (2017). Impact of Electronic Human Resources Management on the Development of Electronic Educational Services in the Universities. International Journal of Engineering and Information Systems, 1(1), 1-19.

Anshori, M., \& Iswati, S. (2019). Metodologi Penelitian Kuantitatif: Edisi 1. Airlangga University Press.

Aristarini, L., Kirya, I. K., \& Yulianthini, N. N. (2014). Pengaruh Pengalaman Kerja, Kompetensi Sosial dan Motivasi Kerja terhadap Kinerja Karyawan pada Bagian Pemasaran PT Adira Finance Singaraja. Jurnal Manajemen Indonesia, 2(1).

Asih, R. (2020). Pengaruh Kompetensi, Motivasi dan Disiplin Kerja Terhadap Kinerja Dosen FEBI Di Institut Agama Islam Negeri Ponorogo. IAIN Ponorogo.

Dewi, N., N. (2019). Kiat-kiat Merangsang Kinerja Dosen PTS. Media Sahabat Cendekia.

Fahlefi, D., R. (2016). Pengaruh Motivasi, dan Disiplin Kerja terhadap Kinerja Dosen dengan Gaya Kepemimpinan Sebagai Variabel Moderating (Studi Kasus Akademi Kesejahteraan Sosial Aks Ibu Kartini Semarang). Jurnal Stie Semarang (Edisi Elektronik), 8(2), 138-156.

Fahrurrozi, M., Jailani, H., \& Putra, Y., R. (2020). Pengaruh Pendidikan Kewirausahan terhadap Minat Berwirausaha dan Motivasi Berwirausaha. JPEK (Jurnal Pendidikan Ekonomi dan Kewirausahaan), 4(2), 265-277.

Hambali, I. (2021). Pengaruh Motivasi dan Pengalaman Kerja terhadap Produktivitas Guru. Jurnal Ilmiah MEA (Manajemen, Ekonomi, \& Akuntansi), 5(1), 316-323.

Hamzah, B., U. (2008). Teori Motivasi dan Pengukurannya. Jakarta: Bumi Aksara.

Hanggraeni, D. (2012). Manajemen Sumber Daya Manusia. Universitas Indonesia Publishing.

Hasibuan, M., S., P., \& dan Motivasi, O. (2005). Dasar Peningkatan Produktivitas. Jakarta: Bumi Aksara Putra.

Hayati, N., \& Lolytasari, L. (2017). Produktivitas dosen UIN Syarif Hidayatullah Jakarta pada Jurnal Terindeks Scopus: Suatu Kajian Bibliometrik. AlMaktabah, 16(1).

Heri, T. (2019). Membangun Produktivitas Dosen di Perguruan Tinggi. Rausyan Fikr: Jurnal Pemikiran dan Pencerahan, 15(2).

Hetharia, H. M., Sailah, I., \& Yulianda, F. (2019). Do Motivation and Competence Influence Civil-Service Lecturers' Performance and Academic Grade Promotion? Jurnal Pendidikan Humaniora, 7(1), 1-10.

Hidayanto, N. (2016). Hubungan Kompensasi Kompetensi Motivasi terhadap Kinerja Dosen di Sekolah TInggi Ilmu Kesehatan Ngudia Husada Madura. JPAP: Jurnal Penelitian Administrasi Publik, 2(02).

Hidayati, Z. Y. F. (2015). Analisis Kompetensi terhadap Penilaian Kinerja Dosen (Studi Kasus Dosen UIN Sultan Syarif Kasim Riau). Kutubkhanah, 17(1), 104-126. 
I'tidal, M., \& Jam'an, A. (2016). Pengaruh Antara Kompetensi, Kompensasi, Motivasi Kerja Dan Pendidikan Terhadap Kinerja Dosen di STIMIK AKBA Makassar. Competitiveness: Jurnal Manajemen dan Bisnis, 5(2), $16-30$.

Kinanti, N. P., \& Zuraida, L. (2018). Analisis Pengaruh Motivasi dan Pengalaman Kerja terhadap Produktivitas Kerja Karyawan PT. Dong Young Tress Indonesia. STIE Widya Wiwaha.

Langford, D., Fellows, R. F., Hancock, M. R., \& Gale, A. W. (2014). Human Resources Management in Construction. Routledge.

Masri, H. A., \& Jaaron, A. A. M. (2017). Assessing Green Human Resources Management Practices in Palestinian Manufacturing Context: An Empirical Study. Journal of Cleaner Production, 143(2), 474-489.

Murcahyanto, M. H., \& Asmawi, M. (2019). Effect of Democratic Leadershipstyle, Organizational Culture On Lecturers' Performance. ICTES 20181 (EAI), Search Proquest.Com.

Ratulangi, R. S., \& Soegoto, A. S. (2016). Pengaruh Pengalaman Kerja, Kompetensi, Motivasi terhadap Kinerja Karyawan (Studi pada PT. Hasjrat Abadi Tendean Manado). Jurnal EMBA: Jurnal Riset Ekonomi, Manajemen, Bisnis Dan Akuntansi, 4(3).

Rohmat, S. (2020). Pengaruh Kompetensi Pegawai dan Motivasi Kerja terhadap Produktivitas Kerja di Balai Kalibrasi Fasilitas Penerbangan. SCIENTIFIC JOURNAL OF REFLECTION: Economic, Accounting, Management and Business, 3(2), 201-210.

Rosmaini, R., \& Tanjung, H. (2019). Pengaruh Kompetensi, Motivasi dan Kepuasan Kerja terhadap Kinerja Pegawai. Maneggio: Jurnal Ilmiah Magister Manajemen, 2(1), 1-15.

Rozada, R. (2020). Pengaruh Kompetensi, Motivasi Kerja dan Disiplin Kerja terhadap Kinerja Dosen pada Fakultas Ekonomi dan Bisnis di Universitas Muhammadiyah Gresik. Universitas Muhammadiyah Gresik.

Sa'adah, M. (2015). Pengaruh Etos Kerja Islami, Pendidikan dan Pengalaman Kerja terhadap Produktivitas Kerja Karyawan (studi pada Rumah Sakit Islam NU Demak). UIN Walisongo.

Samsuni, S. (2017). Manajemen Sumber Daya Manusia. Al-Falah: Jurnal Ilmiah Keislaman dan Kemasyarakatan, 17(1), 113-124.

Sari, D. C. (2015). Pengaruh Lingkungan Kerja dan Senioritas terhadap Produktivitas Kerja Dosen di Jurusan Administrasi Niaga Politeknik Negeri Medan. Jurnal Ilmiah Research Sains, 1(3).

Suharsimi, A. (2006). Metodelogi Penelitian. Yogyakarta: Bina Aksara.

Suliyanto, S. E.. (2017). Metode Penelitian Kuantitatif.

Unaradjan, D. D. (2019). Metode Penelitian Kuantitatif. Penerbit Unika Atma Jaya Jakarta.

Utama, I. (2018). Pengaruh Kompetensi Dosen, Iklim Kerja, Sikap Kerja dan Motivasi Kerja terhadap Produktivitas Kerja Dosen Perguruan Tinggi Swasta di Aceh. UNIMED. 